\title{
PENGARUH LIKUIDITAS, PROFITABILITAS, STRUKTUR MODAL, DAN SUKU BUNGA TERHADAP NILAI PERUSAHAAN
}

\author{
Lulu Meivinia \\ Maksi Fakultas Ekonomi, Universitas Tarumanagara, Jakarta \\ Email: lulumeivinia@gmail.com
}

\begin{abstract}
This study aims to determine the effect of liquidity, profitability and capital structure towards the value of the company with interest rates as moderating variable in companies in mining sector listed on the Indonesia Stock Exchange. The method of determining the sample was by purposive sampling method, with several predetermined criteria, the number of samples obtained were 28 companies in mining sector. Research and testing in applying research hypotheses is the least square technique using Eviews application version 9.0. Research result indicates that liquidity hasno significant effect on firm value, profitability has a significant negative effect on company value, capital structure has no significant effect on company value, and interest rates as moderating variable strengthen the relationship between profitability and company value.
\end{abstract}

Keywords : Liquidity, Profitability, Capital Structure, Interest Rates, Company Value

\section{ABSTRAK}

Penelitian ini bertujuan untuk mengetahui pengaruh likuiditas, profitabilitas dan struktur modal terhadap nilai perusahaan dengan suku bunga sebagai variabel moderasi pada perusahaan sektor pertambangan yang terdaftar di Bursa Efek Indonesia. Metode penentuan sampel dengan metode purposive sampling, dengan beberapa kriteria yang telah ditentukan maka jumlah sampel adalah 28 perusahaan sektor pertambangan. Penelitian dan pengujian dalam menggunakan hipotesis penelitian adalah teknik least square dengan aplikasi Eviews versi 9.0. Hasil penelitian menunjukkan bahwa likuiditas tidak berpengaruh signifikan terhadap nilai perusahaan, profitabilitas berpengaruh signifikan negatif terhadap nilai perusahaan, struktur modal tidak berpengaruh signifikan terhadap nilai perusahaan, dan suku bunga sebagai variabel moderasi memperkuat hubungan antara profitabilitas terhadap nilai perusahaan.

Kata kunci : likuiditas, profitablitas, struktur modal, suku bunga dan nilai perusahaan

\section{PENDAHULUAN}

\section{Latar Belakang}

Menurut Sudiani dan Darmayanti (2016), nilai perusahaan adalah harga pasar dari saham perusahaan yang terbentuk antara pembeli dan penjual di saat terjadi transaksi, karena harga pasar saham dianggap sebagai cerminan dari nilai aset perusahaan yang sesungguhnya. Nilai perusahaan sangat penting karena dengan nilai perusahaan yang tinggi akan diikuti oleh kemakmuran pemegang saham. Nilai perusahaan dapat menggambarkan keadaan perusahaan. Persepsi investor pada tingkat keherhasilan perusahaan dicerminkan melalui nilai perusahaan. Investor yang berinvestasi dana mereka di pasar modal tidak hanya memiliki tujuan jangka pendek, tetapi juga memperoleh pendapatan jangka panjang. Investor harus memanfaatkan semua informasi untuk menganalisis pasar dan berinvestasi dengan harapan untuk mendapatkan keuntungan. Tolak ukur yang sering dipakai untuk mengukur nilai perusahaan adalah price book value, yang dapat diartikan sebagai hasil dari perbandingan antara harga saham dengan nilai buku. Semakin tinggi price book value menunjukkan tingkat kemakmuran pemegang saham yang juga semakin tinggi merupakan tujuan utama dari perusahaan. Menurut Gultom et. al. (2013) , Asiri (2015) dan Karaca dan Savsar (2015), likuiditas, profitabilitas, struktur modal mempengaruhi nilai perusahaan, sedangkan 
menurut Purnomo et.al. (2013) dan Manurung (2016), suku bunga juga mempengaruhi nilai perusahaan.

Beberapa penelitian - penelitian sebelumnya yang menunjukkan likuiditas (CR) berpengaruh signifikan positif terhadap nilai perusahaan yaitu Asiri (2015). Hal yang berbeda ditemukan dalam penelitian Tui et.al. (2017) yang menemukan bahwa pengaruh likuiditas (CR) tidak signifikan terhadap nilai perusahaan. Penelitian Aggarwal dan Padhan (2017) menyatakan pengaruh likuiditas signifikan negatif terhadap nilai perusahaan.

Penelitian Marangu dan Jagongo (2014) dan Nawaiseh (2017) menemukan pengaruh profitabilitas (ROA) signifikan positif terhadap nilai perusahaan. Hasil penelitian yang tidak sama ditemukan pada Menaje (2012) yang menyatakan variabel profitablitas (ROA) berpengaruh negative terhadap nilai perusahaan. Kabajeh et.al. (2012) menemukan ROA berpengaruh positif terhadap harga saham. Dan penelitian Silvana dan Rocky (2013) menemukan pengaruh profitbalitas (ROA) tidak signifikan terhadap nilai perusahaan.

Kodongo et.al. (2014) dan Karava dan Savsar (2015) menyatakan pengaruh struktur modal (DER) tidak signifikan terhadap nilai perusahaan. Lain halnya dengan penelitian Annisa dan Chabachib (2017) yang menemukan pengaruh struktur modal (DER) signifikan positif terhadap nilai perusahaan. Penelitian Chen dan Chen (2011) dan Loncan dan Caldeira (2014) menemukan pengaruh DER signifikan negative terhadap nilai perusahaan.

Penelitian Amperaningrum dan Agung (2011) menemukan pengaruh suku bunga tidak signifikan terhadap pergerakan saham. Hal yang senada juga ditemukan dalam penelitian Jubaedah et.al. (2016) yang menyatakan pengaruh suku bunga tidak signifikan terhadap nilai perusahaan. Penelitian Purnomo dan Widyawati (2013) menemukan pengaruh suku bunga signifikan terhadap return saham. Penelitian Purnomosidi et.al. (2014) menemukan pengaruh suku bunga negatif terhadap nilai perusahaan.

Berdasarkan prapenelitian yang dilakukan oleh peneliti terhadap perusahaan sektor pertambangan yang terdaftar di Bursa Efek Indonesia pada tahun 2012 - 2016, didapat hasil yang tidak sesuai dengan kenyataan teori yang dipaparkan. Trend rata-rata likuiditas, profitabilitas, struktur modal dan suku bunga tahun 2012 -2016 sebagai berikut :

Tabel 1.1:Trend rata-rata likuiditas, profit abilitas, struktur modal dan suku bunga tahun 2012 -2016

\begin{tabular}{|l|c|c|c|c|c|}
\hline \multicolumn{1}{|c|}{$\begin{array}{c}\text { Variabel } \\
\text { Penelitian }\end{array}$} & $\mathbf{2 0 1 2}$ & $\mathbf{2 0 1 3}$ & $\mathbf{2 0 1 4}$ & $\mathbf{2 0 1 5}$ & $\mathbf{2 0 1 6}$ \\
\hline $\begin{array}{l}\text { Nilai Perusahaan } \\
\text { (PBV) }\end{array}$ & 2.51 & 1.82 & 1.80 & 1.18 & 1.39 \\
\hline Likuiditas (CR) & 2.73 & 12.15 & 2.38 & 4.90 & 3.11 \\
\hline $\begin{array}{l}\text { Profitabilitas } \\
\text { (ROA) }\end{array}$ & $8.14 \%$ & $1.18 \%$ & $2.44 \%$ & $-5.37 \%$ & $-0.07 \%$ \\
\hline $\begin{array}{l}\text { Struktur Modal } \\
\text { (DER) }\end{array}$ & $216.91 \%$ & $132.35 \%$ & $125.90 \%$ & $145.70 \%$ & $79.77 \%$ \\
\hline Suku bunga & $5.75 \%$ & $7.50 \%$ & $7.75 \%$ & $7.50 \%$ & $6.50 \%$ \\
\hline
\end{tabular}

Sumber : www.idx.co.id dan www.bi.go.id (Data diolah sendiri, 2017) 
Sesuai tabel 1.1 pada perusahaan sektor pertambangan tahun 2012-2015 terdapat fenomena gap yaitu :

1. Rata-rata likuiditas pada tahun 2013 dan 2015 mengalami peningkatan, sedangkan penurunan trend terjadi pada tahun 2014 dan 2016. Hal ini tidak searah dengan trend nilai perusahaan yang rata-rata dari tahun 2013 - 2015 menurun dan mengalami peningkatan di tahun 2016.

2. Rata - rata profitabilitas menunjukkan trend menurun pada tahun 2013 dan 2015, sedangkan menunjukkan trend meningkat pada tahun 2014 dan 2016. Hal ini juga tidak searah dengan trend nilai perusahaan yang mengalami penurunan pada tahun 2013- 2015 dan peningkatan pada tahun 2016.

3. Rata-rata struktur modal mengalami trend penurunan pada tahun 2013, 2014 dan 2016, sedangkan trend peningkatan pada tahun 2015. Hal ini tidak sejalan dengan trend nilai perusahaan yang pada tahun 2013-2015 mengalami trend penurunan dan trend peningkatan pada tahun 2016.

4. Nilai suku bunga mengalami trend peningkatan pada tahun 2013 dan 2014 dan mengalami penurunan pada tahun 2015 dan 2016. Hal ini tidak sejalan dengan trend nilai perusahaan tahun 2013, 2014 dan 2015 yang mengalami trend yang menurunan dan tahun 2016 mengalami trend yang meningkatan.

Maka dari itu peneliti tertarik untuk mengkaji lebih mendalam faktor-faktor yang diperkirakan dapat mempengaruhi nilai perusahaan pada perusahaan sektor pertambangan yang terdaftar di Bursa Efek Indonesia pada tahun 2012 - 2016.

\section{Kajian Teori}

\section{Capital Structure Theory}

Modigliani dan Miller (1958) menentang pandangan tradisional struktur modal. Mereka berpendapat bahwa struktur modal tidak mempengaruhi nilai perusahaan dengan asumsi - asumsi tidak ada biaya pialang, tidak ada pajak, tidak ada biaya kebangkrutan, investor dapat meminjam pada tingkat yang sama seperti perusahaan dan seluruh investor memiliki informasi yang sama dengan manajemen tentang peluang investasi perusahaan di masa depan. Diasumsikan dalam pasar modal sempurna , tidak ada informasi yang asimetris sehingga para manajer bekerja untuk kepentingan pemegang saham dan perusahaan dapat dikelompokkan dalam kelas resiko yang sama berdasarkan dari resiko bisnis. Kemudian pada awal tahun 1960, Modigliani dan Miller memasukkan faktor pajak ke dalam analisis mereka sehingga mendapat kesimpulan bahwa nilai perusahaan dengan hutang akan lebih tinggi dibandingkan dengan nilai perusahaan tanpa hutang. Kenaikan tersebut dikarenakan adanya penghematan pajak (Chen dan Chen, 2011). Dengan upaya memasukkan berbagai faktor dan menanggalkan satu per satu berbagai ketidak sempurnaan pasar ini melahirkan dua teori keuangan baru dari teori struktur modal yang saling berlawanan yaitu trade-off theory dan pecking order theory.

Trade-off theory menjelaskan bahwa jika posisi struktur modal berada di bawah titik optimal maka setiap penambahan hutang akan meningkatkan nilai perusahaan. Sebaliknya, setiap jika posisi struktur modal berada di atas titik optimal maka setiap penambahan hutang akan menurunkan nilai perusahaan. Esensi trade-off theory dalam struktur modal adalah menyeimbangkan manfaat dan pengorbanan yang timbul sebagai akibat penggunaan hutang. Sejauh manfaat lebih besar, tambahan hutang masih diperkenankan.

Pecking order theory menyatakan bahwa perusahaan lebih memilih umtuk menggunakan internal financing yaitu pendanaan yang berasal dari hasil operasional perusahaan yang berwujud laba ditahan. Apabila pendanaan dari dalam perusahaan belum mencukupi , maka pendanaan dari luar perusahaan akan dibutuhkan, untuk itu perusahaan 
akan menerbitkan obligasi setelah itu sekuritas yang berkarakteristik opsi (seperti obligasi konversi), dan pada akhirnya jika masih belum mencukupi, maka perusahaan akan menerbitkan saham (Chen dan Chen, 2011).

Agency Theory

Teori agensi pada awalnya berkaitan dengan masalah kepemilikan perusahaan melalui pembelian saham. Teori agensi dalam manajemen keuangan membahas adanya hubungan agensi, yaitu hubungan mengenai adanya pemisahan antara kepemilikan dan pengelolaan yang dilakukan oleh manajer. Hubungan agensi seperti ini rawan konflik, yaitu konflik kepentingan pribadi (konflik agensi). Konflik tersebut terjadi karena pemilik modal berusaha menggunakan dana sebaik-baiknya dengan risiko sekecil mungkin, sedangkan manajer cenderung mengambil keputusan pengelolaan dana untuk memaksimalkan keuntungan yang sering bertentangan dan cenderung mengutamakan kepentingannya sendiri. (Jensen dan Meckling, 1976).

Signaling Theory

Asumsi dari signaling theory adalah para manajer perusahaan memiliki informasi yang lebih akurat mengenai perusahaan yang tidak diketahui oleh investor. Hal ini akan mengakibatkan suatu asimetri informasi antara pihak-pihak yang berkepentingan. Asimetri informasi merupakan suatu kondisi dimana infomasi privat yang hanya dimiliki investor-investor yang hanya mendapat informasi saja.

\section{Nilai Perusahaan}

Menurut Keown (2004), nilai perusahaan merupakan nilai pasar atas surat berharga dan ekuitas perusahaan yang beredar. Nilai perusahaan merupakan persepsi investor terhadap tingkat keberhasilan perusahaan yang tercermin pada harga saham, semakin tinggi nilai perusahaan maka semakin besar kemakmuran yang diterima oleh pemilik saham.

Perhitungan price book value (PBV) (Weston et.al. 1998), sebagai berikut:

$$
\text { Price Book Value }=\frac{\text { Market Value }}{\text { Book Value }}
$$

Keterangan

Market value : harga pasar (closing price)

Book value : nilai buku per lembar saham

Likuiditas

Likuiditas menunjukkan kemampuan untuk membayar kewajiban finansial jangka pendek tepat pada waktunya (Subramanyan dan Wild , 2009:223). Semakin tinggi tingkat likuiditas suatu perusahaan semakin tinggi kepastiannya untuk menjadikannya uang tunai.

Perhitungan Current Ratio adalah (Weygandt et.al. , 2012:201), sebagai berikut:

$$
\text { Current Ratio }=\frac{\text { Current Assets }}{\text { Current Liabilities }}
$$

Keterangan

Current Assets : aktiva lancar.

Current Liabilities : hutang lancar 


\section{Profitabilitas}

Profitabilitas merupakan kemampuan perusahaan memperoleh laba dalam hubunganya dengan penjualan, total aktiva maupun modal sendiri (Sartono, 2014:57). Dengan demikian bagi investor jangka panjang akan sangat berkepentingan dengan analisa profitabilitas ini. Profitabilitas menunjukkan kemampuan perusahaan menghasilkan laba dari aktiva yang dipergunakan dan memberikan bukti pendukung mengenai kemampuan perusahaan memperoleh laba dan sejauh mana keefektifan pengelolaan perusahaan.

Perhitungan ROA adalah (Weygandt, 2012:201), sebagai berikut:

Return On Assets $=\frac{\text { Net Income }}{\text { Averaae Assets }}$

Keterangan

Net Income

Average Assets
: Laba bersih perusahaan setelah pajak.

: rata-rata total asset.

\section{Struktur Modal}

Perusahaan mendanai kegiatan operasionalnya dengan menggunakan modal yang didapat dari berbagai sumber. Perpaduan sumber pendanaan dikenal sebagai struktur modal. Struktur modal dapat didefinisikan sebagai perpaduan antara hutang dan ekuitas sebagai sumber pendanaan dalam mencapai tujuan manajemen perusahaan yaitu meningkatkan nilai perusahaan. Neraca perusahaan mencatat perbedaan proporsi modal perusahaan, yaitu porsi hutang dan ekuitas, yang mereprentasikan struktur modal dari perusahaan. Stabilitas keuangan perusahaan dan resiko kebangkrutan dangat bergantung pada sumber pendanaan perusahaan dan tipe dan jumlah asset yang dimiliki oleh perusahaan (Subramanyam dan Wild, 2009:547).

Perhitungan debt to total equity ratio adalah (Weygandt et.al., 2012:201), sebagai berikut:

$$
\text { Debt to total equity }=\frac{\text { Total Debt }}{\text { Total Equity }}
$$

Keterangan

Total Debt : : total hutang

Total Equity : total ekuitas

\section{Suku Bunga}

Suku bunga merupakan tolak ukur dari kegiatan perekonomian suatu negara yang berimbas pada kegiatan perputaran arus keuangan perbankan, inflasi, investasi dan pergerakan mata uang di suatu negara. Sejak pertengahan tahun 2005, dari sisi moneter terjadi perubahan dari stabilisasi yang berbasis jumlah yang beredar menjadi Inflation Targeting Framework dengan menggunakan instrument suku bunga. Pemerintah Indonesia dalam melaksanakan kebijakan moneter, mengumumkan suku bunga acuan yaitu BI rate, yang diharapkan dalam mempengaruhi suku bunga pasar uang dan suku bunga deposito dan suku bunga kredit perbankan. BI rate ini selalu diumumkan kepada publik dan dapat dicari melalui publikasi dan penjelasan Dewan Gubernur, media elektronik, situs resmi Bank Indonesia, press release dan laporan kebijakan moneter. BI Rate diumumkan oleh Dewan Gubernur Bank Indonesia setiap rapat dewan Gubernur 
bulanan. Dengan menggunakan BI rate, kebijakan moneter dapat diterapkan lebih transparan, akuntabel dan mudah dimengerti masyarakat. BI rate berfungsi sebagai sinyal dari kebijakan moneter Bank Indonesia. BI Rate juga merupakan respon bank sentral terhadap tekanan inflasi ke depan agar dapat tetap berada pada sasaran yang telah ditetapkan.

Pengaruh likuiditas terhadap nilai perusahaan

Semakin tinggi likuiditas perusahaan, maka akan semakin banyak dana tersedia bagi perusahaan untuk membiayai operasi dan investasinya, sehingga persepsi investor pada kinerja perusahaan akan meningkat dan selanjutnya berpengaruh pada nilai perusahaan (Anggraini ,2012). Menurut Gultom (2011) bahwa likuiditas yang tinggi memberi arti bahwa perusahaan mampu memenuhi kewajiban jangka pendeknya. Hal ini memberikan sinyal kepada investor bahwa kinerja perusahaan dalam keadaan baik. Asiri (2015) dalam penelitiannya pada perusahaan - perusahaan yang terdaftar di Bursa efek London menemukan adanya pengaruh likuiditas terhadap nilai perusahaan.

Pengaruh profitabilitas terhadap nilai perusahaan.

Profitabilitas merupakan kemampuan perusahaan menghasilkan laba. Semakin tinggi profitabilitas maka akan semakin baik, artinya perusahaan mempunyai kinerja yang bagus dalam menghasilkan laba bersih baik dari hasil penjualan (ROA) maupun modal sendiri (ROE). Untuk menarik minat investor dalam berinvestasi, pihak manajemen akan berusaha untuk meningkatkan profitabilitas perusahaan. Dengan meningkatnya laba, maka akan memberikan dampak positif terhadap peningkatan harga saham di pasar modal, yang berarti nilai perusahaan dalam posisi yang baik. Menurut Hermuningsih (2013), profitabilitas adalah gambaran dari kinerja manajemen dalam mengontrol perusahaan.

Pengaruh struktur modal terhadap nilai perusahaan

Modal merupakan aspek yang penting bagi setiap perusahaan karena mempunyai pengaruh langsung terhadap posisi keuangan perusahaan. Perbandingan antara nilai hutang dengan nilai asset atau ekuitas yang menyebabkan kenaikan harga saham dan nilai perusahaan merupakan struktur modal yang optimal. Pemanfaatan hutang sebagai tambahan modal bagi perusahaan dapat memberikan implikasi bahwa semakin tinggi hutang maka akan semakin tinggi nilai perusahaan. Hal ini biasanya dilakukan oleh perusahaan yang berukuran besar. Perusahaan berskala besar lebih mudah meminjam hutang daripada perusahaan kecil karena kecil kemungkinannya untuk bangkrut. Bila pihak kreditor percaya kepada perusahaan dalam meminjamkan dana, maka itu dapat berarti bahwa perusahaan sedang berkembang dan bertumbuh lebih besar. Manager dapat mengirimkan sinyal kepada investor bahwa ada prospek ke depan yang bagus di perusahaan dengan menggunakan hutang untuk meningkatkan harga saham. Jika harga saham meningkat maka nilai perusahaan juga meningkat. Hal ini menarik bagi investor dan memberikan kepercayaan kepada investor dalam berinvestasi. Sebaliknya semakin tinggi hutang maka akan semakin rendah nilai perusahaan dikarenakan adanya biaya pajak yang semakin besar sehingga akan mengurangi laba perusahaan. Dapat dikatakan bahwa perusahaan lebih memilih untuk meningkatkan modalnya dengan hutang daripada saham. Hal ini tentu saja tidak disukai oleh investor sehingga menyebabkan investor tidak tertarik dalam berinvestasi di perusahaan tersebut. 
Pengaruh suku bunga dalam memoderasi pengaruh antara profitabilitas terhadap nilai perusahaan.

Suku bunga adalah faktor penting yang dapat mempengaruhi perekonomian suatu negara sehingga dapat berpengaruh kuat terhadap pasar modal (Manurung, 2016). Dalam keadaan suku bunga dari bank bagi deposito meningkat, maka investor akan cenderung mengubah keputusan berinvestasinya dari saham ke bank. Hal ini dapat menyebabkan turunnya permintaan akan saham dan menurunnya nilai saham serta akan menurunnya nilai perusahaan. Jika bunga bank untuk deposito meningkat akan menyebabkan tingginya suku bunga pinjaman yang dapat menyebabkan penurunan laba perusahaan dan menyebabkan harga saham dan nilai perusahaan akan turun (Alam dan Uddin, 2009).

\section{Kerangka Pemikiran.}

Kerangka Pemikiran dalam penelitian ini adalah sebagai berikut :

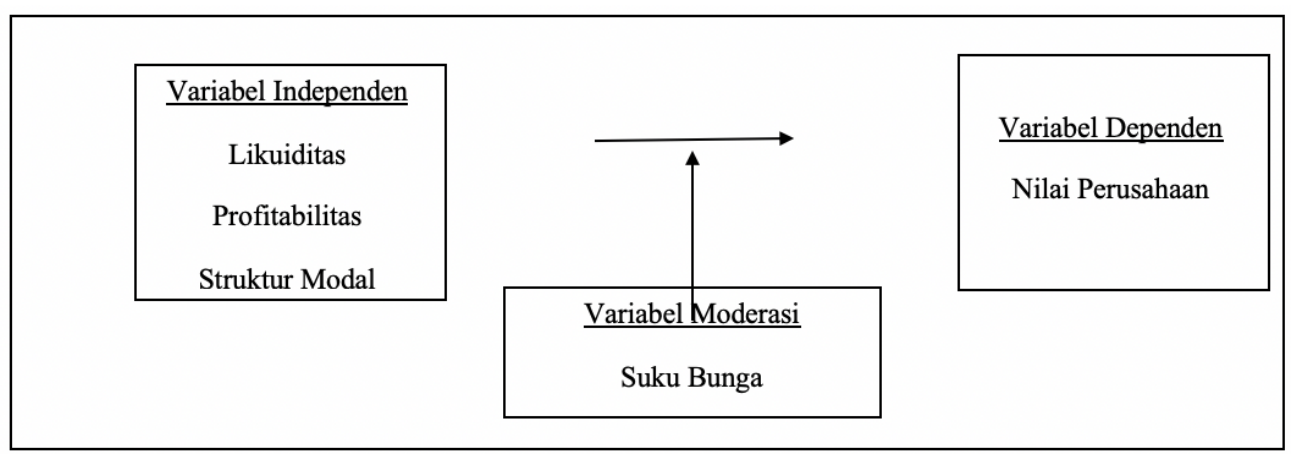

Kerangka Pemikiran

Hipotesis Penelitian. Hipotesis dalam penelitian ini adalah sebagai berikut :

a. Ha1 : Likuiditas berpengaruh signifikan positif terhadap nilai perusahaan.

b. Ha2 : Profitabilitas berpengaruh signifikan positif terhadap nilai perusahaan.

c. Ha3 : Struktur modal berpengaruh signifikan negatif terhadap nilai perusahaan.

d. Ha4: suku bunga sebagai variabel moderasi memperkuat hubungan antara profitabilitas terhadap nilai perusahaan.

\section{METODE PENELITIAN}

Metode Pengumpulan data. Metode pengumpulan data ini dengan cara penelusuran data sekunder di Bursa Efek Indonesia dengan menggunakan website resmi dari www.idx.co.id dan alternatif mendapatkan laporan keuangan tahunan perusahaan didapat dari website masing - masing perusahaan

Populasi dan sampel. Populasi yang digunakan dalam penelitian ini adalah seluruh perusahaan sektor pertambangan yang terdaftar di Bursa Efek Indonesia (BEI) pada tahun 2012 - 2016.

Metode Sampling. Pemilihan sampel penelitian didasarkan pada metode nonprobability sampling tepatnya metode purposive sampling. Menurut Sekaran (2010) metode ini yang membatasi sampel sehingga dapat menyediakan informasi yang dibutuhkan. Adapun kriteria yang digunakan dalam untuk memilih sampel pada penelitian ini adalah sebagai berikut :

1. Perusahaan sektor pertambangan di Bursa Efek Indonesia secara berturut-turut untuk periode 2012-2016

2. Data yang dibutuhkan tersedia lengkap dan menerbitkan laporan keuangan yang telah diaudit oleh auditor independen yang berakhir 31 Desember untuk periode 2012-2016.

Operasional Variabel. Definisikan operasional tiap-tiap variabel sebagai berikut : 
Tabel 4.2

\begin{tabular}{|c|c|c|c|c|c|}
\hline No. & Variabel & Indikator & Rumus Pengukuran & Skala & Sumber \\
\hline 1 & $\begin{array}{c}\text { Nilai } \\
\text { Perusahaan }\end{array}$ & $\begin{array}{c}\text { Price to Book Value } \\
(P B V)\end{array}$ & $\begin{array}{c}\text { Market Value } \\
\text { Book Value }\end{array}$ & Rasio & $\begin{array}{l}\text { Subramanyam dan Wild (2009) } \\
\text { Weygandt, } 2012 \\
\text { Marangu \& Jagongo (2014) } \\
\text { Annisa \& Chabachib (2017) }\end{array}$ \\
\hline 2 & Likuiditas & Current Ratio & $\frac{\text { Current Asset }}{\text { Current Liabilities }}$ & Rasio & $\begin{array}{l}\text { Subramanyam dan Wild (2009) } \\
\text { Weygandt, } 2012 \\
\text { Asiri \& Hameed (2014) } \\
\text { Karaca \& Savsar (2015) }\end{array}$ \\
\hline 3 & Profitabilitas & Return on Asset & $\frac{\text { Net income }}{\text { Average Total Assets }}$ & Rasio & $\begin{array}{l}\text { Subramanyam dan Wild (2009) } \\
\text { Weygandt, } 2012 \\
\text { Asiri \& Hameed (2014) } \\
\text { Karaca \& Savsar (2015) }\end{array}$ \\
\hline 4 & Struktur Modal & Debt to Equity Ratio & $\frac{\text { Total Debt }}{\text { Total Equity }}$ & Rasio & $\begin{array}{l}\text { Subramanyam dan Wild (2009) } \\
\text { Weygandt, } 2012 \\
\text { Asiri \& Hameed (2014) } \\
\text { Karaca \& Savsar (2015) }\end{array}$ \\
\hline 5 & Suku bunga & Suku bunga & BI Rate & Rasio & Bank Indonesia \\
\hline
\end{tabular}

\section{Uji Statistik}

Analisis Statistik Deskriptif. Menurut Ghozali (2011), statistik deskriptif memberikan gambaran atau deskripsi suatu data yang dilihat dari nilai rata - rata (mean), standar deviasi, varian, maksimum, minimum, sum, range, kurtosis (keruncingan distribusi) dan skewness (kemencengan distribusi) dan dalam penelitian ini mengunakan alat bantu untuk menganalisis data adalah program Eviews 9.

Uji Normalitas. Uji normalitas bertujuan untuk menguji apakah dalam model regresi, variabel pengganggu atau residual memiliki distribusi normal (Ghozali, 2013). Dalam penelitian ini, digunakan uji Jarque-Bera untuk melakukan uji distribusi normalitas. Dalam pengujian menggunakan Eviews, jika nilai probabilitas ( $p$-value) lebih besar dari $5 \%$, maka H0 diterima artinya data berdistribusi normal. Namun sebaliknya jika nilai probabilitas probabilitas ( $p$-value) lebih kecil dari 5\%, maka H0 tidak diterima artinya data berdistribusi tidak normal.

Uji Interaksi. Uji interaksi yang disebut dengan Moderated Regression Analysis (MRA), dilakukan dengan mengalikan variabel yang dihipotesiskan sebagai variabel moderasi dengan variabel independennya. Jika variabel hasil perkalian antara variabel independen dengan variabel yang dihipotesiskan sebagai variabel moderating signifikan, maka dapat disimpulkan bahwa variabel yang dihipotesiskan sebagai variabel moderating, benar benar memoderasi hubungan antara variabel independen dengan variabel dependennya.

Uji hipotesis. Uji hipotesis merupakan suatu pengujian yang berkaitan dengan diterima atau tidaknya suatu hipotesis. Pada penelitian ini, menggunakan tingkat kesalahan sebesar $5 \%$. Metode pengujian hipotesis yang digunakan dalam penelitian adalah regresi Least Square dengan metode Fixed Effect. Sarwono (2016:4) mengungkapkan dalam Eviews akan terdapat pilihan fixed effect model dan random effect model. 
Model penelitian yang mencerminkan hipotesis penelitian adalah sebagai berikut :

\begin{tabular}{ll|}
\hline & $\mathrm{NP}=\mathrm{a}+\beta 1 \mathrm{LQ}+\beta 2 \mathrm{PR}+\beta 3 \mathrm{SM}+\beta 4 \mathrm{PR} . \mathrm{SB}+\mathrm{e}$ \\
$\mathrm{a}$ & $=$ nilai konstanta \\
$\beta 1, \beta 2, \beta 3, \beta 4$ & $=$ koefisien regresi \\
$\mathrm{NP}$ & $=$ Nilai Perusahaan \\
$\mathrm{LQ}$ & $=$ Likuiditas \\
$\mathrm{PR}$ & $=$ Profitabilitas \\
$\mathrm{SM}$ & $=$ Struktur Modal \\
$\mathrm{SB}$ & $=$ Suku Bunga \\
$\mathrm{e}$ & $=$ error
\end{tabular}

Analisis koefisien determinasi (Uji Adjusted $\mathrm{R}^{2}$ ). Menurut Sarwono 2016, adjusted $\mathrm{R}^{2}$ menyatakan jumlah persentase varian variabel dependen dalam model regresi. Nilai adjusted $\mathrm{R}^{2}$ mencerminkan kebenaran hubungan yang mendasar antara variabel independen dan variabel dependen dari model regresi. Untuk melihat persentase besar variabel independen dan variabel moderating mempengaruhi variabel dependen, maka dapat dilihat dari nilai adjusted $R$-squared.

Uji hipotesis parsial. Dalam metode least square nilai probabilitas (prob) digunakan untuk menguji masing masing variabel independen secara parsial dalam menerangkan variabel-variabel independen. Pengambilan keputusan adalah sebagai berikut :

a. Jika nilai prob lebih besar atau sama dengan 5\%, maka $\mathrm{H} 0$ diterima yang berarti bahwa variabel independen tidak berpengaruh terhadap variabel dependen.

b. Jika nilai prob lebih kecil dari 5\%, maka $\mathrm{H} 0$ ditolak yang berarti bahwa variabel independen berpengaruh terhadap variabel dependen.

Uji Hipotesis Simultan. Menurut Ghozali 2016, uji pengaruh simultan digunakan untuk mengetahui apakah variabel independen dan variabel moderating secara bersama-sama simultan mempengaruhi variabel dependen. Uji hipotesis akan menggunakan Probability $(F$-statistic). Pengambilan keputusan adalah sebagai berikut :

a. Jika nilai Probability ( $F$-statistic) lebih besar atau sama dengan 5\%, maka $\mathrm{H} 0$ diterima yang berarti bahwa variabel independen tidak berpengaruh terhadap variabel dependen.

b. Jika nilai Probability ( $F$-statistic) lebih kecil dari 5\%, maka H0 ditolak yang berarti bahwa variabel independen berpengaruh terhadap variabel dependen.

\section{HASIL DAN PEMBAHASAN}

Hasil Uji Normalitas. Uji Normalitas bertujuan untuk menguji apakah dalam model regresi, variabel pengganggu atau residual memiliki distribusi normal. Penentuan data dengan uji Jacque-Bera dengan nilai signifikasi sebesar 0.05 atau 5\% . Berikut ini adalah hasil Uji Normalitas: 
Tabel 4.3 Hasil Uji Normalitas Jacque-Bera

\begin{tabular}{|l|c|c|c|c|c|c|}
\hline & NP & LQ & PR & SM & SB & PR_SB \\
\hline Mean & 1.673669 & 2.359221 & 0.023804 & 1.551255 & 0.070000 & 0.001511 \\
\hline Median & 1.099267 & 1.620873 & 0.026566 & 0.749176 & 0.075000 & 0.001745 \\
\hline Maximum & 12.27174 & 20.16748 & 0.492421 & 14.81267 & 0.077500 & 0.028314 \\
\hline Minimum & 0.163703 & 0.005887 & -0.587174 & -15.81731 & 0.057500 & -0.044038 \\
\hline Std. Dev. & 1.825573 & 3.083814 & 0.121683 & 3.020530 & 0.007610 & 0.008399 \\
\hline Skewness & 3.300112 & 3.947770 & -0.973670 & 0.884442 & -0.645046 & -1.539404 \\
\hline Kurtosis & 16.61366 & 20.03837 & 9.778746 & 16.41891 & 1.781664 & 11.03836 \\
\hline Jarque-Bera & 1335.218 & 2057.099 & 290.1706 & 1068.643 & 18.36731 & 432.2170 \\
\hline Probability & 0.000000 & 0.000000 & 0.000000 & 0.000000 & 0.000103 & 0.000000 \\
\hline & & & & & & \\
\hline Sum & 234.3137 & 330.2910 & 3.332557 & 217.1758 & 9.800000 & 0.211559 \\
\hline Sum Sq. Dev. & 463.2474 & 1321.877 & 2.058145 & 1268.180 & 0.008050 & 0.009804 \\
\hline Observations & & & & & & \\
\hline
\end{tabular}

Berdasarkan tabel di atas, hasil pengujian terhadap normalitas residual dengan menggunakan uji Jacque-Bera adalah sebagai berikut :

a. Variabel likuiditas (LQ) menghasilkan nilai Jarque-Bera sebesar 2057 dengan nilai probability sebesar 0.000 . Nilai probability lebih kecil dari nilai signifikan 0.05 . Hal ini berarti data residual terdistribusi tidak normal.

b. Variabel profitabilitas (PR) menghasilkan nilai Jarque-Bera sebesar 290 dengan nilai probability sebesar 0.0000 . Nilai probability lebih kecil dari nilai signifikan 0.05 . Hal ini berarti data residual terdistribusi tidak normal.

c. Variabel struktur modal (SM) menghasilkan nilai Jarque-Bera sebesar 1068 dengan nilai probability sebesar 0.0000 . Nilai probability lebih kecil dari nilai signifikan 0.05. Hal ini berarti data residual terdistribusi tidak normal.

d. Variabel nilai perusahaan (NP) menghasilkan nilai Jarque-Bera sebesar 1335 dengan nilai probability sebesar 0.0000 . Nilai probability lebih kecil dari nilai signifikan 0.05 . Hal ini berarti data residual terdistribusi tidak normal.

e. Variabel suku bunga yang memoderasi profitabilitas (PR_SB) menghasilkan nilai Jarque-Bera sebesar 432 dengan nilai probability sebesar 0.0000. Nilai probability lebih kecil dari nilai signifikan 0.05 . Hal ini berarti data residual terdistribusi tidak normal.

Melalui hasil pengujian ini, dapat dinyatakan bahwa variabel likuiditas, profitabilitas, struktur modal serta suku bunga yang memoderasi profitabilitas dinyatakan tidak terdistribusi secara normal karena nilai signifikansi dari hasil pengujian lebih kecil dari 0.05 .

Hasil Uji Hipotesis. Pengujian ini menggunakan Regresi Least Square. Berikut hasil uji hipotesis menggunakan Eviews 9. 
Tabel 4.4 Hasil Uji Hipotesis

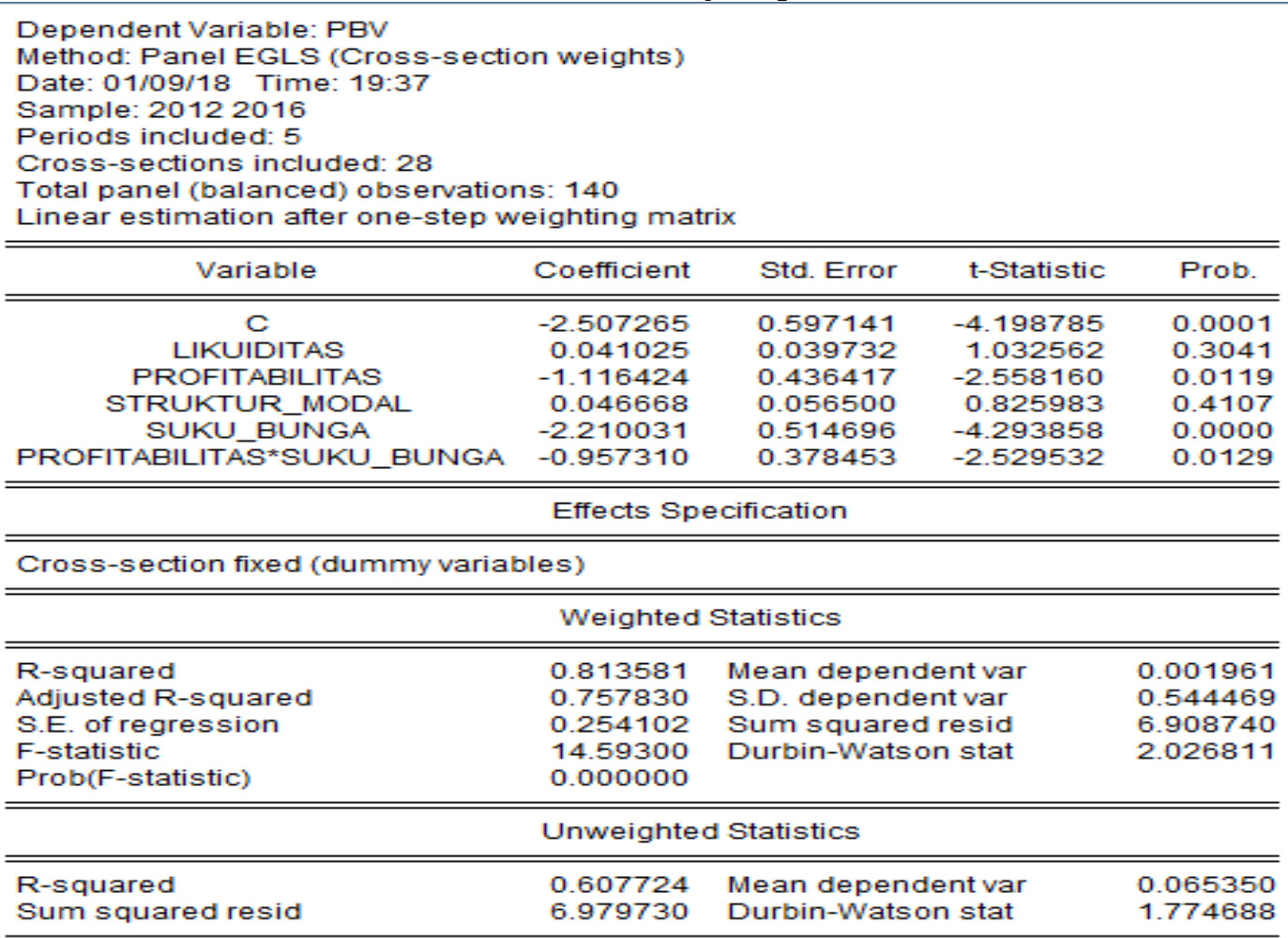

Berdasarkan tabel 4.4, maka persamaan regresi penelitian adalah sebagai berikut:

\begin{tabular}{|c|c|}
\hline \multicolumn{2}{|c|}{$\mathrm{PBV} / \mathrm{NP}=-2.50+0.04 \mathrm{LQ}-1.11 \mathrm{PR}+0.04 \mathrm{SM}-0.95 \mathrm{PR} * \mathrm{SB}+\mathrm{e}$} \\
\hline PBV/NP & $=$ Nilai Perusahaan \\
\hline LQ & $=$ Likuiditas \\
\hline PR & $=$ Profitabilitas \\
\hline SM & $=$ Struktur Modal \\
\hline SB & $=$ Suku Bunga \\
\hline e & $=$ error \\
\hline
\end{tabular}

Dari persamaan regresi penelitian diatas yang didapat dari hasil tabel 4.4 , diketahui sebagai berikut:

- Konstanta dalam penelitian ini sebesar -2.50 menyatakan bahwa jika variabel independen dianggap konstan, maka rata - rata nilai perusahaan sebagai variabel dependen sebesar -2.50 .

- Koefisien regresi likuidasi (LQ) sebesar 0.04 menyatakan bahwa setiap penambahan likuidasi akan meningkatkan nilai perusahaan sebesar 0.04.

- Koefisien regresi Profitabilitas (PR) sebesar -1.11 menyatakan bahwa setiap penambahan profitabilitas akan menurunkan nilai perusahaan sebesar 1.11.

- $\quad$ Koefisien regresi Struktur Modal (SM) sebesar 0.04 menyatakan bahwa setiap penambahan struktur modal akan meningkatkan nilai perusahaan sebesar 0.04.

- $\quad$ Koefisien regresi untuk variabel moderasi suku bunga $(\mathrm{PR} * \mathrm{SB})$ sebesar -0.95 menyatakan bahwa setiap penambahan struktur modal akan menurunkan nilai perusahaan sebesar 0.95 . 
Uji Interaksi (Moderated Regression Analysis). Dalam uji interaksi yang dapat dilihat pada tabel 4.4, diketahui bahwa suku bunga yang diregresikan dengan variabel dependen, mempunyai nilai Prob 0.0000 berada dibawah tingkat signifikan 0.05. Hal ini menunjukkan bahwa suku bunga sebagai variabel independen berpengaruh signifikan terhadap nilai perusahaan. Persamaan regresi untuk uji interaksi variabel suku bunga dengan variabel nilai perusahaan sebagai variabel dependen yaitu sebagai berikut :

$\mathrm{NP}=-2.50+0.04 \mathrm{LQ}-1.11 \mathrm{PR}+0.04 \mathrm{SM}-2.21 \mathrm{SB}-0.95 \mathrm{PR} * \mathrm{SB}+\mathrm{e}$

Variabel interaksi adalah pengalian variabel independen dengan variabel moderasi. Dalam tabel 4.4 diketahui bahwa variabel independen adalah profitabilitas yang dikalikan dengan variabel moderasi yaitu suku bunga, sehingga menghasilkan variabel interaksi yaitu PR*SB. Variabel interaksi sesuai dengan tabel 4.4 mempunyai nilai prob. sebesar 0.0129 lebih kecil dari tingkat signifikan 0.05, sehingga variabel interaksi signifikan terhadap nilai perusahaan. Persamaan regresi untuk uji interaksi variabel suku bunga dengan variabel nilai perusahaan sebagai variabel dependen yaitu sebagai berikut :

$\mathrm{NP}=-2.50+0.04 \mathrm{LQ}-1.11 \mathrm{PR}+0.04 \mathrm{SM}-0.95 \mathrm{PR} * \mathrm{SB}+\mathrm{e}$

Menurut Ghozali (2016:214), jika persamaan i dengan koefisien $\beta$ SB dan persamaan ii dengan koefisien $\beta$ PR*SB mempunyai pengaruh yang signifikan, maka variabel tersebut merupakan variabel kuasi moderator. Maka dari itu, suku bunga dalam penelitian ini adalah kuasi moderator yang mempunyai arti bahwa suku bunga memoderasi pengaruh profitabilitas terhadap nilai perusahaan.

Koefisien Determinasi. Koefisien determinasi ( $R$-squared) mengukur seberapa jauh kemampuan model dalam menerangkan variasi variabel dependen (Ghozali,2016:95). Nilai menurut table 4.4 sebesar 0.8135 , hal ini mencerminkan besarnya variabel dependen yaitu nilai perusahaan yang dijelaskan dengan menggunakan variabel independen berupa likuiditas, profitabilitas, struktur modal, suku bunga sebesar $81.35 \%$, sedangkan sisanya sebesar $18.65 \%$ dipengaruhi oleh variabel lain diluar penelitian ini.

Menurut Sarwono (2016:31) , nilai Adjusted $R$ square adalah nilai yang sering digunakan sebagai nilai kecocokan model (goodness of fit) dimana jika nilainya semakin tinggi (mendekati 1), model semakin benar/akurat. Nilai Adjusted $R$ square selalu lebih kecil dari nilai $R$-squared. Hal ini dapat dilihat dari table 4.4 yang menunjukkan nilai Adjusted $R$ square sebesar 0.7578 .

Uji Signifikansi Simultan (Uji F). Berdasarkan uji F didapat Prob (F-statistic) 0.000000 , karena probabilitas jauh lebih kecil dari 0.05 maka model regresi dapat digunakan untuk memprediksi bahwa likuiditas, profitabilitas, struktur modal dan suku bunga dalam menjelaskan nilai perusahaan.

Uji Signifikansi Parsial (Uji Statistik t). Berdasarkan hasil uji statistik t dapat diketahui hanya profitabilitas yang mempunyai pengaruh signifikan terhadap nilai perusahaan.

Diskusi. Berdasarkan penelitian yang telah dilakukan, secara rinci mengenai hasil pengujian dapat dijelaskan sebagai berikut :

a. $\mathrm{Ha}_{1}$ : Likuiditas berpengaruh signifikan positif terhadap nilai perusahaan.

Hasil pengujian yang dilakukan dengan menggunakan Uji t untuk mengetahui pengaruh variabel likuiditas menemukan bukti empiris yang menunjukkan bahwa likuiditas mempunyai pengaruh negatif dan tidak signifikan terhadap nilai perusahaan. Dengan demikian, maka dalam penelitian ini $\mathrm{H}_{\mathrm{a} 1}$ ditolak yaitu likuiditas tidak 
berpengaruh signifikan terhadap nilai perusahaan. Penelitian ini tidak sejalan dengan penelitian yang dilakukan oleh Ozlen dan Erqun (2012), Kohansal et. al. (2013), Asiri (2015), Winarto (2015) dan Marsha dan Murtaqi (2017). Dan sejalan dengan penelitian Hasan (2011), Gultom et.al. (2013), Asiri dan Hameed (2014), Kausar et.al. (2014) dan Sudiani dan Darmayanti (2016). Pada dasarnya likuiditas merupakan kemampuan perusahaan dalam memenuhi kewajiban jangka pendek hal ini akan berdampak pada meningkatkan nilai perusahaan.

b. $\mathrm{Ha}_{2}$ : Profitabilitas berpengaruh signifikan positif terhadap nilai perusahaan.

Hasil pengujian yang dilakukan dengan menggunakan Uji $t$ untuk mengetahui pengaruh variabel profitabilitas menemukan bukti empiris yang menunjukkan bahwa profitabilitas mempunyai pengaruh signifikan negatif terhadap nilai perusahaan. Dengan demikian, maka dalam penelitian ini $\mathrm{H}_{\mathrm{a} 2}$ diterima yaitu profitabilitas berpengaruh signifikan terhadap nilai perusahaan. Hasil penelitian ini tidak mendukung penelitian Marangu dan Jagongo (2014), Asiri (2015), Annisa dan Chabachib (2017) dan Nawaiseh (2017) dan mendukung penelitian sebelumnya yaitu Menaje (2012) dan Aggarwal dan Padhan (2017). Menurut Jock O'Callaghan selaku Global Mining leader di $P w C$, beberapa tahun terakhir merupakan tahun yang berat bagi perusahaan pertambangan disertai dengan adanya kenaikan suku bunga sehingga investor cenderung memilih investasi deposito dibandingkan dengan saham.

c. $\mathrm{Ha}_{3}$ : Struktur modal berpengaruh signifikan negatif terhadap nilai perusahaan.

Hasil pengujian yang dilakukan dengan menggunakan Uji t untuk mengetahui pengaruh variabel struktur modal menemukan bukti empiris yang menunjukkan bahwa struktur modal mempunyai pengaruh positif dan tidak signifikan terhadap nilai perusahaan. Dengan demikian, maka dalam penelitian ini $\mathrm{H}_{\mathrm{a} 3}$ ditolak yaitu struktur modal tidak berpengaruh signifikan negatif terhadap nilai perusahaan. Penelitian ini tidak sejalan dengan Chen dan Chen (2011), Loncan dan Caldeira (2014), Kodongo et. al. (2014) dan Dewi (2016). Sedangkan penelitian ini sejalan dengan Purnomosidi et.al. (2014), Winarto (2015), Karaca dan Savsar (2015), Annisa dan Chabachib (2017). Struktur modal menjadi peranan yang sangat penting bagi perusahaan. Keputusan pendanaan menjadi relevan, maka penggunaan hutang untuk membiayai aset operasional akan berdampak pada meningkatkan nilai perusahaan.

d. Ha 4 : suku bunga sebagai variabel moderasi memperkuat hubungan antara profitabilitas terhadap nilai perusahaan.

Hasil pengujian yang dilakukan dengan menggunakan Uji $\mathrm{t}$ untuk mengetahui hubungan variabel suku bunga yang signifikan negatif memoderasi profitabilitas terhadap nilai perusahaan. Dengan demikian, maka dalam penelitian ini $\mathrm{H}_{\mathrm{a} 4}$ diterima yaitu suku bunga sebagai variabel moderasi memperkuat hubungan antara profitabilitas terhadap nilai perusahaan. Hasil penelitian ini mendukung penelitian Purnomo dan Widyawati (2013) dan Purnomosidi et.al. (2014). Dan tidak mendukung penelitian Amperaningrum dan Agung (2011) dan Jubaedah et. al. (2016).

\section{SARAN DAN KESIMPULAN}

Saran Penelitian. Berdasarkan hasil penelitian yang telah dilakukan, maka saran yang dapat diberikan oleh peneliti adalah sebagai berikut :

1. Penelitian ini diharapkan menjadi referensi untuk penelitian selanjutnya mengenai faktor-faktor yang mempengaruhi nilai perusahaan sebagai berikut :

a. Menggunakan objek penelitian yang lebih luas, tidak hanya pada perusahaan sektor pertambangan. Lebih baik dapat memperluas penelitian yaitu seluruh perusahaan yang terdaftar di Bursa Efek Indonesia. 
b. Mengunakan faktor faktor internal lainnya yang kemungkinan mempengaruhi nilai perusahaan seperti kebijakan dividen, ukuran perusahaan dan pertumbuhan aset perusahaan, sehingga dapat lebih mencerminkan kondisi internal perusahaan.

c. Menggunakan faktor-faktor eksternal lainnya yang kemungkinan mempengaruhi nilai perusahaan seperti inflasi, kurs valuta asing, harga batubara dunia maupun harga minyak dunia.

2. Bagi praktisi dan pengguna lainnya, yaitu bagi investor atau calon investor yang hendak melakukan investasi di pasar modal agar mempertimbangkan return on assets dan suku bunga sebagai variabel moderasi dalam memprediksi nilai perusahaan, karena secara simultan dan parsial kedua variabel independen tersebut memiliki pengaruh yang signifikan.

3. Bagi pihak mamajemen perusahaan untuk lebih meningkatkan kinerja keuangan maupun kinerja keseluruhan manajemen di perusahaan setiap tahunnya agar dapat meningkatkan kepercayaan investor untuk berinvestasi di perusahaan. Untuk meningkatkan kinerja perusahaan dapat dilakukan dengan cara mengelola modal yang ada untuk kegiatan yang dapat meningkatkan nilai perusahaan.

\section{REFERENSI}

Asiri, B.K., \& Hameed.A. S.(2014). Financial Ratios and Firm's Value in the Bahrain Bourse. Research Journal of Finance and Accounting Vol.5, No.7.

Asiri, Batool. (2015). How Investors Perceive Financial Ratios at Different Growth Opportunities and Financial Leverages. Journal of Business Studies Quarterly, Vol. 6, No. 3.

Chen,J. L., \& Chen, Y. S. (2011). The influence of profitability on firm value with capital structure as the mediator and firm size and industry as moderators. Investment Management and Financial Innovations, Vol. 8, Issue 3.

Kabajeh, M.A.M., Nu'aimat, S.M.A., Dahmash. F.A. (2012). The Relationship between the ROA, ROE and ROI Ratios with Jordanian Insurance Public Companies Market Share Prices. International Journal of Humanities and Social Science, Vol.2, No. 11.

Karaca, S.S., \& Savsar, A. (2015). The Effect of Financial Ratios on The Firm Value : Evidence from Turkey. Journal of Applied Economic Sciences.

Kohansal, Reza,M., Dadrasmoghaddam,A., Karmozdi,M.K., \& Mohseni.A. (2013). Relationship between Financial Ratios and Stock Prices for the Food Industry Firms in Stock Exchange of Iran.World Applied Programming, Vol 3, Issue (10), pp: 512-521.

Kodongo, O., Mokoteli, T., \& Maina. L . (2014). Capital Structure, Profitability and Firm Value : Panel Evidence of Listed Firms in Kenya. MPRA Paper No. 57116, posted 6.

Menaje.,Placido Jr. (2012). Impact of Selected Financial Variables on Share Price of Publicly Listed Firms in the Philippines. American International Journal of Contemporary Research, Vol. 2 No. 9.

Winarto, Jacinta. (2015). The Determinants of Manufacturer Firm Value in Indonesia Stock Exchange. International Journal of Information Business and Management, Vol.7, No.4. 